${ }^{2}$ Клініка «ОПТИМАЛ»

- м. Вінниця, Україна

\title{
ОПТИЧНА КОГЕРЕНТНА ТОМОГРАФІЯ У ДІАГНОСТИЦІ МІОПIÏ РІЗНОГО СТУПЕНЯ СЕРЕД ДІТЕЙ 3 НЕДИФЕРЕНЦІЙОВАНОЮ ФОРМОЮ ДИСПЛАЗІЇ СПОЛУЧНОЇ ТКАНИНИ
}

\begin{abstract}
Недиференційована форма дисплазії сполучної тканини (НДСТ) призводить до змін сполучнотканинного каркасу очного яблука та характеризується збільшенням його передньо-заднього розміру (ПЗР). Мета роботи - дослідити структури очного яблука при міопії у поєднанні з НДСТ серед дітей Подільського регіону, використовуючи метод оптичної когерентної томографії (ОКТ). Результат дослідження вказує на достовірні морфометричні зміни у центральній зоні сітківки при збільшеному ПЗР та кореляційний зв'язок цих показників 3 гостротою зору у дітей-міопів з НДСТ. У висновку ми розглядаємо міопію як головний діагностичний критерій НДСТ та можливий іiі злоякісний перебіг при даному синдромі.

Ключові слова: оптична когерентна томографія, міопія, діти, дисплазія сполучної тканини.
\end{abstract}

Згідно даних ВОО3, короткозорість посідає провідне місце серед аномалій рефракцій, прогресуюча форма якої характеризується рядом ускладнень, що можуть призвести до зниження якості життя, ранньої інвалідизації дітей та підлітків, що суттєво впливає на соціалізацію та профорієнтацію. Тому для ВОО3 пріоритетними $\epsilon$ завдання вдосконалення діагностики, профілактики, лікування міопії та ії ускладнень.

Оптична когерентна томографія - сучасний метод діагностики, який базується на використанні люмінесцентного світлодіоду, за допомогою якого відбувається сканування прозорих середовищ ока та вимірювання часу затримки світлового променя, що відбивається від тканин ока [7]. Слід зазначити, що цей метод дозволяє проводити прижиттєве гістологічне дослідження структур очного яблука. ОКТ набув широкого використання у визначенні морфології рогівки, кута передньої камери, структур сітківки [10]. На сьогодні з'явилась можливість проведення ОКТ-ангіографії - експрес-метода, який дозволяє діагностувати стан судинної системи заднього відрізка ока [9]. Також цей метод широко використовується при дослідженні аномалій рефракції, зокрема короткозорості, різні ступені якої стали для нас предметом дослідження при недиференційованій формі синдрому дисплазії сполучної тканини.

Відомо, що НДСТ є генетично-детермінованим станом, в основі якого лежить порушений синтез сполучної тканини, що, в свою чергу, призводить до порушення іiі функцій. Л.Н. Аббакумова повідомляє, що в педіатрії найчастіше для визначення ступеня вираженості ДСТ використовують діагностичні критерії Т. Мілковскої-Димитрової, відповідно до яких виділяється всього 15 головних ознак та незначні другорядні зміни. Також повідомляється про міопію як один 3 фенотипів НДСТ [1].

Фіброзна оболонка ока представлена склерою та рогівкою - сполучнотканинне утворення, що викликає особливу зацікавленість для проведення дослідження. Адже існуючі поодинокі теоретичні та експериментальні дані, котрі стосуються змін сполучнотканинного каркасу очного яблука при НДСТ, у повному обсязі не розкривають причинно-наслідкового зв’язку з патологією [3].

Українські вчені також проводять дослідження у даному напрямку, досліджуючи біомеханічні особливості структур очного яблука при НДСТ. Так, у роботі Цибульської Т.Є., Завгородньої Т.С. повідомляється про зниження корнеального гістерезису у групі дітей-міопів, порівнюючи 3 групою здорових дітей. Ними встановлено кореляційний зв'язок цього параметра зі збільшенням передньо-заднього відрізка очного яблука при міопії, що, на думку вчених, може свідчити про зміни міцносних властивостей сполучнотканинного каркасу очного яблука [6]. Значимим, для нашої роботи, є досвід Горбатюк Т.Л. у вивченні морфометричних та функціональних показників структур сітківки серед дітей-міопів у Вінницькій та Одеській областях. У дослідженні вперше були показані зміни товщини сітківки, наявність деформації шару пігментного епітелію, перипапілярних волокон ДЗН. Результати стосувались групи дітей-міопів 3 
рефракцією більше 4,5 дптр та аксіальним розміром очного яблука більше 25,3 мм, що у 80,6\% випадків, як показав дискримінантний аналіз даних, мали прогресуючу міопію [4].

Мета роботи: дослідити структури очного яблука при короткозорості у поєднанні з НДСТ серед дітей Подільського регіону, використовуючи метод оптичної когерентної томографії.

Матеріали і методи. Виконано офтальмологічне дослідження 47 дітям (94 ока) віком від 4 до 17 років (середній вік 11,6 року $\pm 3,7$ року). Дослідження проводилось у групі обстежених осіб - 17 чоловічої та 30 жіночої статі зі встановленим діагнозом короткозоpicmь. Усі пацієнти мешкають у Вінницькій області.

Основними критеріями відбору пацієнтів були: наявність короткозорості різного ступеня у поєднанні з іншими екстраокулярними ознаками недиференційованої форми дисплазії сполучної тканини. НДСТ підтверджувався за умови наявності певних зовнішніх i/aбо внутрішніх фенотипових ознак (наявності патології шкіри, опорно-рухової системи, м'язової, сечовидільної, дихальної, серцево-судинної, травної систем тощо). Ступінь вираженості НДСТ визначався за діагностичними критеріями Т. Мілковскої-Димитрової. Легкий ступінь дисплазії діагностується за наявності всього двох головних ознак, середній - при прояві у хворого 3-4 головних та двох другорядних, виражений - при наявності 5 і більше головних ознак та 3-4 другорядних.

Дітям основної та контрольної груп проведено ряд офтальмологічних клінічних досліджень: визначення гостроти зору та визначення гостроти зору з повною корекцією, авторефрактометрію (HUVITZ, HRK7000, Auto-Ref/Keratometer, Корея), біомікроскопію, офтальмоскопію, ультразвукову біометрію (ТОМЕY, biometer AL-100, A-SCAN, Японія). Метод оптичної когерентної томографії (технологія Spectral Domain OCT, SOCT Copernicus REVO, Польща). Вони проводились за стандартними протоколами з урахуванням морфометричних показників: товщини сіт- ківки у фовеа та у восьми парафовеолярних секторах (внутрішньо-верхній, -нижній, -назальний, -темпоральний та зовнішньо-верхній, -нижній, -назальний, -темпоральний - відповідно. ОКТ пахіметрія рогівки: центральної зони та периферичних сегментів. Також проводилось ОКТ дослідження соска зорового нерва, а саме: враховувались середні показники товщини нейропапілярного шару. Порівнювали зазначені показники у короткозорих дітей з НДСТ та без нього.

У ході дослідження використовувались методи статистичного аналізу за допомогою програми SPSS Statistics. Математико-статистичну обробку результатів проводили за допомогою описової статистики $(\mathrm{M} \pm \mathrm{m})$, міжгрупові порівняння показників проводили за допомогою критерія Стьюдента для незалежних вибірок. Рівень статистичної значимості відмінностей рахували при $\mathrm{p}<0,05$.

Результати та їх обговорення. Серед обстежених 47 дітей-міопів недиференційовану форму дисплазії сполучної тканини виявлено у 25 віком від 4 до 17 років (середній вік $11,6 \pm 4,1$ року). У дітей без НДСТ кількість очей зі слабким, середнім та високим ступенем міопії складала $73 \%, 7 \%$ та $11 \%$, відповідно. Частка еметропічних очей цієї групи складала $9 \%$. У дітей з НДСТ спостерігали достовірне посилення міопічної рефракції - кількість очей зі слабким, середнім та високим ступенем міопії у цій групі складала $50 \%, 20 \%$ та $26 \%$, відповідно ( $\mathrm{p}=0,02)$.

За всіма дослідженими показниками визначеними окремо для правого та лівого ока, відмінності між міопами з та без НДСТ мали недостатній рівень статистичної значущості (p>0,1), хоча отримані дані ОКТ-пахіметрії (табл. 1, 2) та ОКТ центральної зони сітківки (див. рис.), для обох груп відрізнялись у негативному відношенні для групи дітей-міопів 3 НДСТ. Можливо, такий результат був обумовлений недостатньою кількістю обстежених.

Підтвердженням даного припущення є те, що аналіз даних з урахуванням показників усіх очей у кожній $з$ груп виявив ряд достовірних закономірностей.

ОКТ-пахіметрія 22 дітей-міопів (44 ока) без екстраокулярних проявів НДСТ

\begin{tabular}{|c|c|c|c|c|c|c|}
\hline \multirow[b]{2}{*}{ Сектор рогівки } & \multicolumn{2}{|c|}{ Праве око } & \multirow[b]{2}{*}{$N$} & \multicolumn{2}{|c|}{ Ліве око } & \multirow[b]{2}{*}{$N$} \\
\hline & середній показник & $\begin{array}{c}\text { стандартне } \\
\text { відхилення }\end{array}$ & & середній показник & $\begin{array}{c}\text { стандартне } \\
\text { відхилення }\end{array}$ & \\
\hline центр & 540,1818 & 34,97296 & 22 & 541,3182 & 33,87145 & 22 \\
\hline верхній & 562,5909 & 37,35883 & 22 & 567,0455 & 37,37006 & 22 \\
\hline верхній назальний & 564,7273 & 37,02532 & 22 & 565,1364 & 35,80808 & 22 \\
\hline назальний & 561,8636 & 36,30335 & 22 & 559,3636 & 35,81240 & 22 \\
\hline нижній назальний & 556,8182 & 36,04182 & 22 & 553,4091 & 34,94166 & 22 \\
\hline нижній & 550,2727 & 35,42017 & 22 & 549,5909 & 33,95888 & 22 \\
\hline нижній темпоральний & 543,6818 & 35,67897 & 22 & 547,5455 & 35,21867 & 22 \\
\hline темпоральний & 543,4545 & 35,53634 & 22 & 549,7273 & 36,17574 & 22 \\
\hline верхній темпоральний & 553,3636 & 36,61062 & 22 & 559,5909 & 37,21707 & 22 \\
\hline
\end{tabular}


ОКТ-пахіметрія 25 дітей-міопів (50 очей) з екстраокулярними проявами НДСТ

\begin{tabular}{|c|c|c|c|c|c|c|}
\hline \multirow{2}{*}{ Сектор рогівки } & \multicolumn{2}{|c|}{ Праве око } & \multicolumn{3}{|c|}{ Ліве око } \\
\cline { 2 - 3 } & середній показник & $\begin{array}{c}\text { стандартне } \\
\text { відхилення }\end{array}$ & \multirow{2}{*}{$N^{*}$} & середній показник & $\begin{array}{c}\text { стандартне } \\
\text { відхилення }\end{array}$ & 36,07417 \\
\hline центр & 534,5200 & 35,36491 & 25 & 532,9583 & 24 \\
\hline верхній & 556,3043 & 38,68925 & 23 & 557,0833 & 36,94522 & 24 \\
\hline верхній назальний & 558,9130 & 37,74666 & 23 & 559,0833 & 35,88135 & 24 \\
\hline назальний & 555,2174 & 36,60596 & 23 & 555,4583 & 36,04343 & 24 \\
\hline нижній назальний & 550,9565 & 34,94083 & 23 & 552,4167 & 35,32079 & 24 \\
\hline нижній & 545,2174 & 34,92584 & 23 & 547,2083 & 35,53318 & 24 \\
\hline нижній темпоральний & 538,3478 & 33,94194 & 23 & 540,1250 & 35,00101 & 24 \\
\hline темпоральний & 537,5652 & 34,03985 & 23 & 538,2917 & 34,02490 & 24 \\
\hline верхній темпоральний & 547,0870 & 36,27661 & 23 & 547,3750 & 34,13377 & 24 \\
\hline
\end{tabular}

Примітка:

* - у двох випадках обстеження не виконано у повному обсязі. Відсутня фіксація через наявність ністагму та амбліопії високого ступеня

Середні морфофункціональні показники зі стандартним відхиленням

Таблиия 3 для сумарної кількості очей у досліджуваних групах

\begin{tabular}{|c|c|c|c|}
\hline Показник & Міопія без НДСТ $(n=44)$ & Міопія з НДСТ $(n=50)$ & $P$ \\
\hline \multicolumn{4}{|c|}{ OCT } \\
\hline пахіметрія (товщина центру рогівки), мк, $\mathrm{M} \pm \mathrm{SE}$ & $540,75 \pm 3,61$ & $533,76 \pm 3,55$ & 0,17 \\
\hline $\begin{array}{c}\text { товщина сітківки у fovea, } \\
\text { мк } M, \mathrm{M} \pm \mathrm{SE} \\
\end{array}$ & $198,40 \pm 2,53$ & $212,45 \pm 5,65$ & 0,03 \\
\hline $\begin{array}{l}\text { товщина шару нейроепітеліальних волокон ДЗН, мк } м \text {, } \\
\qquad \begin{array}{l}\text { M } \\
\text { SE }\end{array}\end{array}$ & $128,71 \pm 1,16$ & $125,51 \pm 0,30$ & 0,06 \\
\hline \multicolumn{4}{|c|}{$\begin{array}{r}\text { УЗД біометрія } \\
\end{array}$} \\
\hline$\Pi 3 \mathrm{P}, м \mu, \mathrm{M} \pm \mathrm{SE}$ & $24,09 \pm 0,10$ & $24,94 \pm 0,20$ & $<0,001$ \\
\hline \multicolumn{4}{|c|}{ Візометрія } \\
\hline гострота зору, $\mathrm{M} \pm \mathrm{SE}$ & $0,50 \pm 0,04$ & $0,28 \pm 0,03$ & $<0,0001$ \\
\hline
\end{tabular}

Виявлено, що гострота зору у міопів з НДСТ значно нижча порівняно з міопами без фенотипових ознак

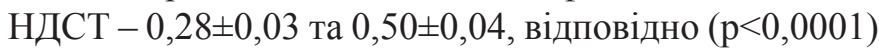
(табл. 3). ПЗР у групі осіб з НДСТ достовірно біль-

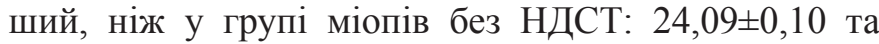
$24,94 \pm 0,20$ відповідно ( $<<0,001)$. Отримані результати свідчать, що у дітей-міопів з НДСТ зміна морфологічних показників структур очного яблука, а саме достовірне збільшення ПЗР, корелює зі значним зниженням гостроти зору.

За результатами досліджень, отриманих у представленій роботі, нами було виявлено достовірне потовщання центральної зони макули у дітей міопів 3

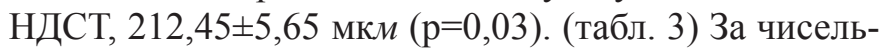
ними даними літератури, при прогресуючій міопії спостерігається потоншання парафовеолярної зони, що також спостерігається у нашому дослідженні. Подібне потоншання може бути закономірним проявом процесів, обумовлених збільшенням аксіального розміру очного яблука, що спостерігається при змінах сполучнотканинного каркаса склери [8]. В окремих дослідженнях було показано, що таке потовщання, саме у fovea, при потоншанні парамакулярних ділянок характерне для прогресуючої та вродженої міопії,
Середній показник із стандартним відхиленням товщини центральної зони сітківки групи дітей-міопів із екстраокулярними ознаками НДСТ

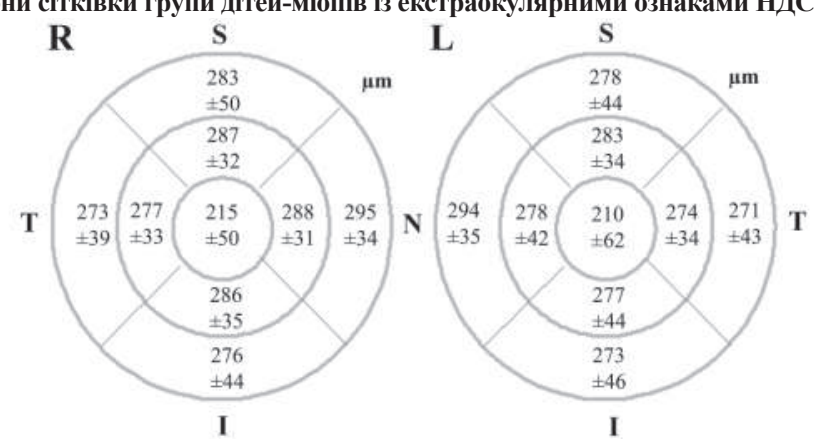

Середній показник із стандартним відхиленням товщини центральної зони сітківки групи дітей-міопів без екстраокулярних ознак НДСТ

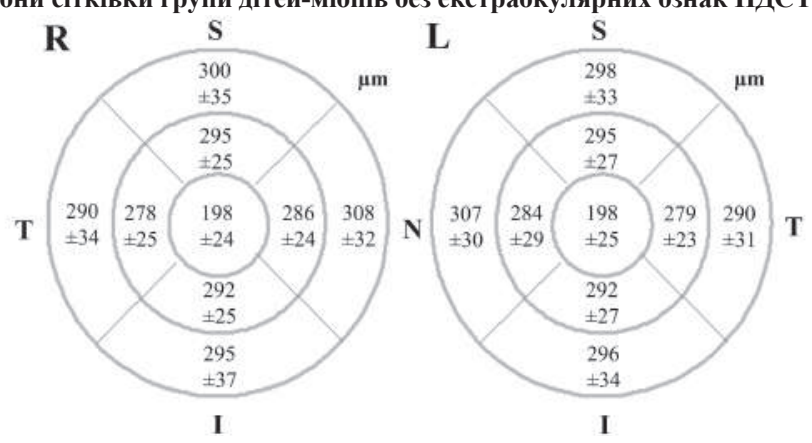

Рис. Схематичне зображення секторів центральної зони сітківки для правого та лівого ока дітей-міопів у досліджуваних групах 
цьому є ряд підтверджень у роботах з використанням ОКТ [5]. У роботі Аветисова С.Е. та інш. показано, що при міопії високого ступеня у дорослих пацієнтів (середній вік 42 17,34 року) товщина сітківки у фовеальній зоні коливалась у широкому діапазоні - від 135 до 835 мкм. Автори пояснюють подібні зміни тим, що при сумарному зростанні товщини сітківки в фовеальній зоні відбувається зменшення товщини фоторецепторного шару, який «маскується» збільшеною товщиною внутрішніх шарів сітківки [2]. Також спостерігається тенденція до потоншання шару нейроепітеліальних волокон ДЗН у дітей-міопів з НДСТ: 125,51 $\pm 0,30$ $(\mathrm{p}=0,06)$ (табл. 3). Отримані дані можуть свідчити про патоморфологічні зміни структури ДЗН у дітей-міопів внаслідок видовження заднього полюса очного яблука, що може бути пов'язане $з$ диспластичними процесами у сполучнотканинному каркасі очного яблука. За результатами ОСТ пахіметрії не виявлено достовірних відмінностей між товщиною центральної частини рогівки у дітей-міопів з та без НДСТ: 540,75 33,61 мкм і $533,76 \pm 3,55$ мкм відповідно ( $=0,17)$.

\section{Висновки}

1. Серед обстежених 47 дітей-міопів (94 ока) у 25 (50 очей) виявлено НДСТ. Проведено статистичну обробку з наступним аналізом офтальмологічних даних. Виявлено достовірні відмінності між показниками в досліджуваних групах. Для дітей-міопів з НДСТ характерне: зниження гостроти зору майже вдвічі до 0,28 на обох очах ( $<<0,0001)$; збільшення ПЗР очного яблука на 0,9 мм ( $<<0,001)$; потовщання шарів сітківки у fovea $212,45 \pm 5,65$ мкм $(\mathrm{p}=0,03)$; тенденція до потоншання шару нейроепітеліальних волокон ДЗН 125,51 $\pm 0,30$ мкм ( $\mathrm{p}=0,06)$; проте за результатами пахіметрії не виявлено достовірних відмінностей між товщиною центральної частини рогівки у дітей-міопів з та без НДСТ ( $\mathrm{p}=0,17)$, що може свідчити про більш складний та опосередкований характер змін колагену у фіброзній оболонці ока з розвитком міопії.

2. Отримані дані вказують, що наявність НДСТ може бути фактором ризику у розвитку прогресуючої форми короткозорості і вказувати на міопію як першочерговий прояв НДСТ. Цей складний процес пов'язаний зі змінами у складі сполучної тканини фіброзної оболонки очного яблука, як наслідок - збільшення його аксіального розміру. Видовження заднього полюсу призводить до появи осьової міопії. Розвиток та нестабільність процесу призводять до неконтрольованого зниження гостроти зору, а згодом - до змін морфології центральної частини сітківки, а саме: потоншання парафовеолярної ділянки та потовщання у фовеа, потоншання нейроепітелію соска зорового нерва.

3. Використання ОКТ та інших стандартних методів діагностики дозволило детально виявити відмінності у параметрах структур очного яблука у дітей досліджуваних груп. Це дає змогу вчасно виявити патологію, зосередитись на підходах щодо профілактики злоякісної форми міопії, яка, в свою чергу, призводить до незворотних морфологічних змін.

\section{Література}

1. Аббакумова Л. Н. Клинические формы дисплазии соединительной ткани у детей / Л. Н. Аббакумова. - СПб., 2006. - 36 с.

2. Аветисов C. Э. Анализ изменений центральной зоны глазного дна при миопии по данным флуоресцентной ангиографии и оптической когерентной томографии / С. Э. Аветисов, М. В. Будзинская, О. А. Жабина [и др.] // Вестник офтальмологии. - 2015. - Т. 131, № 4. - С. 38-48.

3. Баринов Э. Ф. Особенности строения и метаболизма соединительных тканей глаза / Э. Ф. Баринов, О. Н. Сулева, К. Э. Голубов, Т. В. Маслакова // Офтальмологический журнал. - 2011. - № 4. C. 92-97.

4. Бойчук И. М. Морфоструктурные особенности сетчатки и зрительного нерва у школьников с миопией / И. М. Бойчук, Т. Л. Горбатюк // Вісник морфології. - 2009. - Т. 15, № 2. - С. 427-429.

5. Маркосян Г. А. Толщина сетчатки в макулярной области у детей с врожденной и приобретенной миопией высокой степени по данным оптической когерентной томографии / Г. А. Маркосян, Е. П. Тарутта, М. В. Рябина // Российский офтальмологический журнал. - 2010. - Т. 3, № 3. - С. 21-24.

6. Цыбульская T. Е. Особенности биомеханических и биометрических параметров корнеосклеральной капсулы глазного яблока у детей с миопией / Т. Е. Цыбульская, Т. С. Завгородняя //Сучасні медичні технології. - 2013. - № 4. - С. 115-119.

7. Шаимов Т. Б. Периферические дистрофии сетчатки. Оптическая когерентная томография. Лазерная коагуляция сетчатки: атлас // Глава 1. Методы и принципы ОКТ-сканирования периферии сетчатки. / Т. Б. Шаимов, А. Ю. Галин, А. В. Фомин, под ред. В. А. Шаимовой. - СПб., 2015. - С. 10-21.

8. Lim M. C. Use of optical coherence tomography to assess variations in macular retinal thickness in myopia / M. C. Lim, S. T. Hoh, P. J. Foster [et al.] // Investigative Ophthalmology \& Visual Science. 2005. - Vol. 46, № 3. - C. 974-978.

9. Matsunaga $D$. OCT angiography in healthy human subjects / D. Matsunaga, J. Yi, C. A. Puliafito, A. H. Kashani // Ophthalmic Surgery, Lasers and Imaging Retina. - 2014. - Vol. 45, № 6. - C. 510-515.

10. Targowski $P$. Complex spectral OCT in human eye imaging in vivo / P. Targowski, M. Wojtkowski , A. Kowalczyk [et al.] // Optics Communications. 2004. - Vol. 229 (1-6). - C. 79-84. 


\title{
ОПТИЧЕСКАЯ КОГЕРЕНТНАЯ ТОМОГРАФИЯ В ДИАГНОСТИКЕ МИОПИИ РАЗНОЙ СТЕПЕНИ У ДЕТЕЙ С НЕДИФФЕРЕНЦИРОВАННОЙ ФОРМОЙ ДИСПЛАЗИИ СОЕДИНИТЕЛЬНОЙ ТКАНИ
}

\author{
Н. В. Малачкова, Д. А. Яцченко, Е. М. Радёга
}

Недифференцированная форма дисплазии соединительной ткани (НДСТ) приводит к изменениям соединительнотканного каркаса глазного яблока и характеризуется увеличением его передне-заднего размера (ПЗР). Цель работы - исследование структур глазного яблока при миопии в сочетании с НДСТ среди детей Подольского региона, используя метод оптической когерентной томографии (ОКТ). Результат исследования указывает на достоверные морфометрические изменения в центральной зоне сетчатки при увеличенном ПЗР и корреляционную связь этих показателей с остротой зрения у детей-миопов с НДСТ. В заключении мы рассматриваем близорукость как главный диагностический критерий НДСТ и возможность ее злокачественного течения при данном синдроме.

Ключевые слова: оптическая когерентная томография, миопия, дети, дисплазия соединительной ткани.

\section{OPTICAL COHERENT TOMOGRAPHY IN THE DIAGNOSIS OF MYOPIA OF DIFFERENT DEGREES AMONG CHILDREN WITH UNDIFFERENTIATED FORM OF DYSPLASIA OF CONNECTIVE TISSUE}

\author{
N. V. Malachkova ${ }^{1}$, D. A. Yatsenko ${ }^{1}$, K. M. Radoha ${ }^{2}$
}

${ }^{1}$ Pirogov Vinnytsya National Pirogov Memorial Medical University of the Ministry of Public Health of Ukraine Vinnitsya, Ukraine,

${ }^{2}$ Center «Optimal»

Vinnitsya, Ukraine

The undifferentiated type of dysplasia of the connective tissue (UDCT) leads to changes in the connective tissue of the eye globe and increases its axial size. Under certain pathogenic conditions, this process may become unstable. When instability occurs, this leads to the progression of myopia, characterized by a constant, gradual decrease in visual acuity. Together with changes in the fibrous skin of the eye, changes in the vasculature and retina take place. Over time, this leads to degenerative changes in the related ocular structures.

A detailed diagnosis of the central area of the retina and the optic nerve disk is not possible without using the optical coherent tomography (OCT) method. This is a modern diagnostic method based on the use of a fluorescent light-emitting diode, by which the scanning of transparent eye environments is carried out, and the time delay of the light beam reflected from the eye tissues is measured. It should be noted that the method allows the attending physician, or ophthalmologist to conduct a lifetime histological examination of the structures of the eyeball.

The purpose of the current work is to study the structures of the eyeball in myopia, in combination with NDST among children of the Podilskyi region, using the method of optical coherent tomography.

The result of the research shows the faithful morphometric changes in the central area of the retina with higher axial size of the eye globe and correlative relationship with visual acuity of myopic children with UDCT.

Conclusion. The low vison leads to impairment of children's and junior's social adaptation, professional orientation and influences the quality of life. The reason is high myopia that can manifest as the single sign and with another extraocular pathology with connective tissue dysplasia.

The main ophthalmic methods of diagnostic with extra OCT method permit finding out morphologic changes in eye layers and concentrate on the preventive measures of high myopia.

Key words: optical coherent tomography, myopia, children, dysplasia of connective tissue.

Стаття надійшла до редакції 06.08.2018 p. 